\title{
Water Issues
}

\begin{abstract}
he United Nations General Assembly proclaimed 2003 as the International Year of Freshwater. This year should encourage Governments, the United Nations System, and all other actors to take advantage to increase awareness of the importance of sustainable freshwater use, its management and protection. With the present issue of GAIA, we would like to contribute to these efforts. The various papers shed light on the different quantitative and qualitative aspects of freshwater use. With this editorial, we would like to draw your attention to some of the main water issues, which will challenge and accompany us the next two decades.
\end{abstract}

Fair fresh water distribution between humans and nature, and between all sectors will be one of the main challenges of the $21^{\text {st }}$ century. Four sectors compete for water, namely water for people, industries and services (restaurants, hospitals, and so on), water for agriculture, water for nature, and water for energy production. A number of water-related issues are relevant for each sector, though with a different degree of importance. These issues relate to water quality, water quantity, (urban) water infrastructure and integrated water management, and socio-economics and institutional aspects.

Annual water needs per sector, where appropriate for industrialized countries. The per person use for ecosystems, other systems and river-runoffs are calculated for comparison with a world population of 6 billion people. The numbers represent average values and are from different sources. The estimated annual rainfall onto the continents is between $99000 \mathrm{~km}^{3}$ and $119000 \mathrm{~km}^{3}$ (Gleick, 1993).

\begin{tabular}{lcc}
\hline Sector & $\mathrm{km}^{3}$ per year & $\mathrm{m}^{3}$ per person and year \\
\hline $\begin{array}{l}\text { Water for humans } \\
\text { (drinkwater, hygiene, luxury activities, services, industry) }\end{array}$ & 1340 & 223 \\
Water for agriculture & 7200 & 1200 \\
Water for ecosystems & 56472 & 9412 \\
$\begin{array}{l}\text { Other systems } \\
\text { (evaporation from lakes, reservoirs, tundra, deserts, etc.) }\end{array}$ & 6770 & 1129 \\
Runoff through major rivers & 46770 & 7795 \\
\hline Total & 118552 & 19759 \\
\hline
\end{tabular}

"How much water does a person need for survival, how much is necessary for a decent life we are used to in the OECD countries?" Three liters of drinking water per day and person in temperate zones and about nine liters in the tropics represent the absolute minimum. Additional 30 to 50 liters per person and day is considered to be satisfactory for cooking, keeping up a basic personal and domestic hygiene, and washing. A total of approximately 50 liters per day at an excellent quality can be regarded as basic human need allowing a decent and healthy life. This amount of water is a human right. Its supply to all citizens at affordable costs should be the goal for each and every government. In 2000 one sixth (1.1 billion people) of the world's population was without access to 50 liters per day at sufficient quality.

For luxury use, such as watering the garden, washing the car, filling the swimming pool and flushing the water closets, additional 100 to 250 liters have to be delivered per day. Hospitals, restaurants, hotels, and other institutions use a considerable amount of water. 100 liters per capita and day is estimated in Europe. Industry needs approximately 300 liters. Pricing for this part of the water use should follow free market mechanisms. Under the current supply-driven water markets, infrastructures for all the potential water uses are being put in place. A demand-driven market may distinguish better between the various users and quality claims, and would allow a more efficient water management. The public private partnership could be more successful when based on such a differentiated quantitative approach in water supply. The local public institutions are responsible for the first 50 liters, either through own supply or subsidies to the private sector to assure quality and delivery of the basic human needs. The rest of the water is an economic good, the price of which is fixed through free market mechanisms taking into account costs for production and distribution infrastructure.

Besides drinking, hygiene, and shelter, food is also essential. Food production consumes much more water than generally appreciated. Depending on how the water is brought to the plant, between 0.1 and 1.2 kilograms of cereals are produced with 1000 liters of water supplied. The generic rule of thumb is one kilogram of bread per cubic meter of water. Since meat is produced from plant material and the conversion factor ranges between 6 and 20 percent, approximately 6000 liter water is necessary for obtaining one kilogram of beef. 


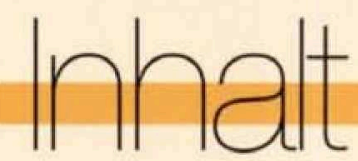

A diet with 20 percent meat and a daily caloric intake of $2500 \mathrm{kcal}$ per person, results in a virtual water consumption of an additional 3300 liters of water per person and day.

There are already a number of countries at the South-rim of the Mediterranean, the near East, and the Arabic peninsula which have not enough renewable water for drinking water supply, service functions and industry, and for agricultural production. The lacking water is compensated by food import. Most of the countries currently compensating water by food imports are economically strong and can afford it. With the future demographic development, more but economically much weaker countries will fall into this category. As a consequence, the adequate and just access to agricultural products needs to be internationally guaranteed. Right now such a guarantee does not exist. The main food-exporting countries (in the order of importance USA, France, Canada, Australia, and Argentina) are in the developed "North" and some of them have used their position in the global food market for their own political interests.

Satisfying the need for water is to satisfy a basic physiological need. As long as physiological needs are not met, there is no incentive to fulfill other human needs, like security, social and cultural welfare, esteem, et cetera. On a global scale, freshwater is not lacking. Water quality, management of the water, and the uneven regional distribution of rainfalls with all its consequences are the problems we are faced to solve in the coming years. Most technologies are already available to markedly improve the efficiency of water use and to deliver everywhere good quality of water. Depending on the local or regional availability of drinking water its production based on purification, detoxification or desalination processes preferentially driven by regenerative energy sources will become ever more important, in some remote areas or on islands its disposability is vital.

What is needed now are new approaches in water management, together with a contract between countries, or better, a global solidarity, comparable to what led to the foundation of the United Nations, particularly in the food sector. The lessons of the past demonstrate that we must make a decisive break from past policies to new sustainable approaches that are comprehensive, where needed market-oriented, and participatory. The implementation of new approaches will require difficult decisions on the part of all of us. But one fundamental point is clear: we have no choice. At stake are our health, our economies, and the integrity of our societies.

Alexander J.B. Zehnder

Swiss Federal Institute for Environmental Science and Technology (EAWAG), Dübendorf www.eawag.ch

Armin Reller

Environmental Science Center (WZU), University of Augsburg www.wzu.uni-augsburg.de

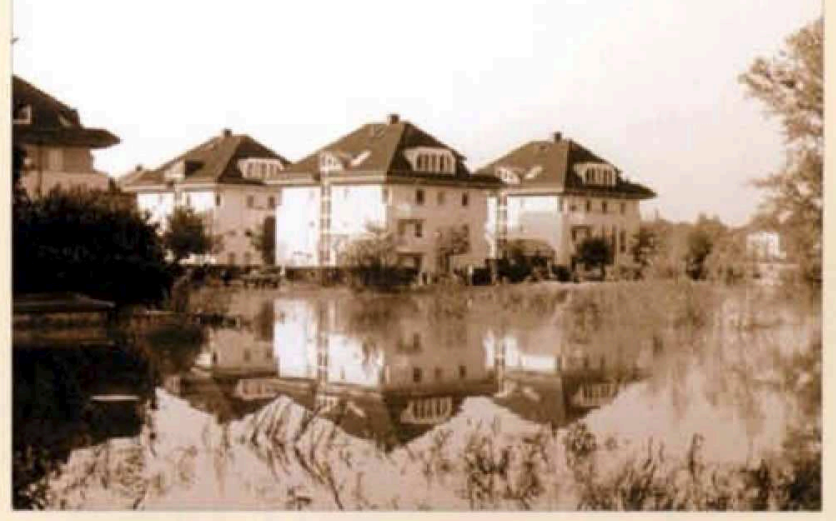

Die Hochwasserkatastrophe wieder einmal vorbei, die Schadensbilanz geschluckt und bald verschmerzt, Normalităt kehrt zurūck. Weiter so? Steigende Schadens- und Wertschỏpfungspotentiale erfordern einen Übergang zum Hochwasserrisikomanagement. Was tun Wissenschaft und Forschung?

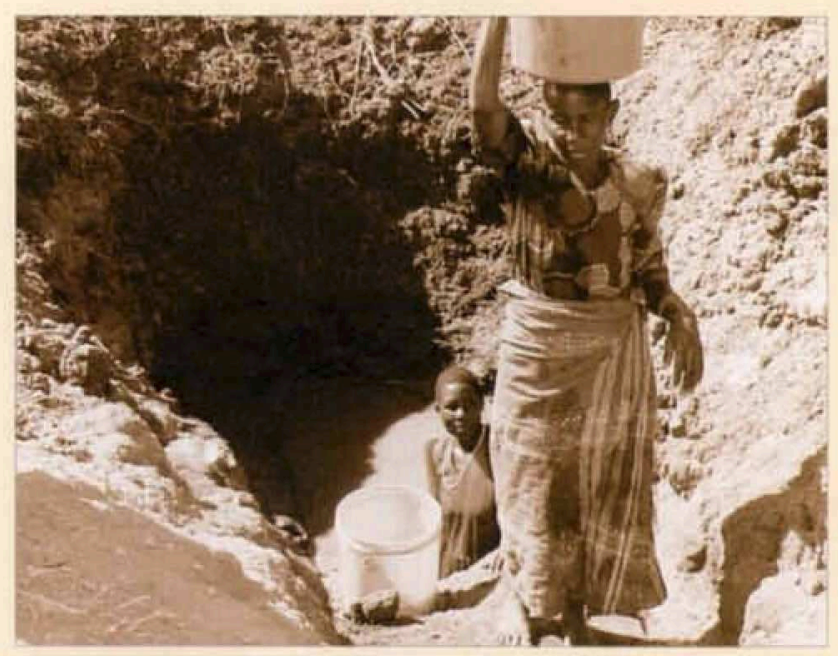

In Trockengebieten wie Wüste, Steppe, Savanne mit wenig Regen und starker Verdunstung bleibt die Wasserversorgung für Millionen Menschen eine tägliche Mühsal. Notwendig wäre eine Verbesserung der Versorgungssicherheit durch angepaßte, robuste Technik und alternative Energien.

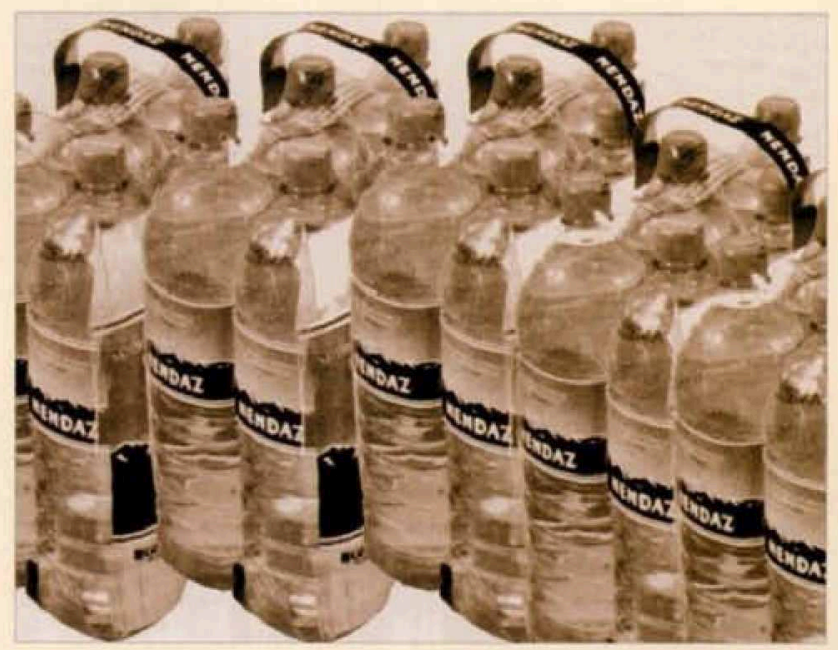

Bei Wasser und Brot sitzen, das ist als verhüllender Ausdruck für Knast schieben längst out. Jetzt werden nämlich Wasser und Brot in Hüllen verpackt und als Massen-, Marken- oder Luxusartikel vermarktet. Bottled Water gehört zum Lifestyle 70 - aber paßt es auch zu nachhaltigem Konsum? 